\title{
Central urocortin 3 and type 2 corticotropin-releasing factor receptor in the regulation of energy homeostasis: critical involvement of the ventromedial hypothalamus
}

\author{
Peilin Chen ${ }^{1+}$, Christine Van Hover ${ }^{2+}$, Daniel Lindberg ${ }^{1}$ and Chien $\mathrm{Li}^{1}{ }^{*}$ \\ 1 Department of Pharmacology, University of Virginia Health System, Charlottesville, VA, USA \\ ${ }^{2}$ Department of Neuroscience, University of Virginia Health System, Charlottesville, VA, USA
}

\author{
Edited by: \\ Hubert Vaudry, University of Rouen, \\ France \\ Reviewed by: \\ Tamás Kozicz, Radboud University \\ Nijmegen, Netherlands \\ Eric Zorrilla, The Scripps Research \\ Institute, USA

\section{*Correspondence:} \\ Chien Li, Department of \\ Pharmacology, University of Virginia \\ Health System, P.O. Box 800735, \\ 1300 Jefferson Park Avenue, \\ Charlottesville, VA 22908, USA \\ e-mail: cl4xd@virginia.edu \\ tPeilin Chen and Christine Van Hover \\ have contributed equally to this work.
}

The vital role of the corticotropin-releasing factor (CRF) peptide family in the brain in coordinating response to stress has been extensively documented. The effects of CRF are mediated by two G-protein-coupled receptors, type 1 and type 2 CRF receptors $\left(\mathrm{CRF}_{1}\right.$ and $\mathrm{CRF}_{2}$ ). While the functional role of $\mathrm{CRF}_{1}$ in hormonal and behavioral adaptation to stress is well-known, the physiological significance of $\mathrm{CRF}_{2}$ remains to be fully appreciated. Accumulating evidence has indicated that $\mathrm{CRF}_{2}$ and its selective ligands including urocortin 3 (Ucn 3) are important molecular mediators in regulating energy balance. Ucn 3 is the latest addition of the CRF family of peptides and is highly selective for $\mathrm{CRF}_{2}$. Recent studies have shown that central Ucn 3 is important in a number of homeostatic functions including suppression of feeding, regulation of blood glucose levels, and thermoregulation, thus reinforcing the functional role of central $\mathrm{CRF}_{2}$ in metabolic regulation. The brain loci that mediate the central effects of Ucn 3 remain to be fully determined. Anatomical and functional evidence has suggested that the ventromedial hypothalamus $(\mathrm{VMH})$, where $\mathrm{CRF}_{2}$ is prominently expressed, appears to be instrumental in mediating the effects of Ucn 3 on energy balance, permitting Ucn 3-mediated modulation of feeding and glycemic control. Thus, the Ucn 3-VMH CRF 2 system is an important neural pathway in the regulation of energy homeostasis and potentially plays a critical role in energy adaptation in response to metabolic perturbations and stress to maintain energy balance.

Keywords: CRF, Ucn 3, VMH, energy balance, feeding, glucose

\section{INTRODUCTION}

Corticotropin-releasing factor (CRF) was discovered in 1981 by Vale and colleagues at the Salk Institute (Vale et al., 1981). Its existence had been hypothesized for many years prior to the 1981 paper characterizing the amino acid sequence of the peptide. Since then, the importance of CRF family of peptides and receptors in stress has steadily emerged. Extensive investigation has demonstrated that CRF is critical in regulating the hypothalamic-pituitaryadrenal (HPA) axis and in integrating endocrine, autonomic, and behavioral responses to stressors (Perrin and Vale, 1999).

In addition to CRF, additional members of the CRF peptide family including urocortins (Ucns) 1, 2, and 3 have been identified in mammals, including humans (Vaughan et al., 1995; Hsu and Hsueh, 2001; Lewis et al., 2001; Reyes et al., 2001). Accumulating evidence suggests that the central actions of Ucn peptides may account for some stress-related effects originally attributed to CRF (Bale and Vale, 2004; Hashimoto et al., 2004; Venihaki et al., 2004; Jamieson et al., 2006; Kuperman et al., 2010). For example, Ucn 1 appears to be involved in the later stage of the stress response and adaptation to stress, while Ucns 2 and 3 may be involved in attenuating the stress response (Ryabinin et al., 2012).

Additionally, the Ucns have been shown to be involved in various physiological regulations including energy balance, cardiovascular function, and behavioral modulation. Ucn 1, 2, and
3 all suppress feeding (Spina et al., 1996; Hashimoto et al., 2004; Fekete et al., 2007), and deficiency in Ucn 2 improves glucose and insulin homeostasis (Chen et al., 2006). Ucn 1 and 2 decrease cardiac output and heart rate, and may be protective against ischemia (Latchman, 2002; Bale et al., 2004; Hashimoto et al., 2004). Behaviorally, Ucn 1 plays a critical role in anxiety-like and depressive behavior, and may be involved in the predisposition of alcohol consumption (Vetter et al., 2002; Ryabinin et al., 2012). Ucn 2 may be linked to depression but not anxiety (Ryabinin et al., 2012). Ucn 2 appears to influence social behavior, including aggression (Breu et al., 2012), as mice deficient in Ucn 2 are less aggressive and prefer passive social interaction. Finally, Ucn 1 and CRF receptors have been found in the auditory system (Graham et al., 2010) and the peptide appears to be involved in the development and maintenance of hearing (Vetter et al., 2002).

Urocortin 3 is the latest addition of the CRF family of peptides, initially identified in the brains of humans and rodents (Hsu and Hsueh, 2001; Lewis et al., 2001). Sequence analyses show that Ucn 3 is more closely related to Ucn 2 than Ucn 1 or CRF. Human and mouse Ucn 3 share 40\% homology with human and mouse Ucn 2, but only 21 and 18\%, respectively, with human and mouse Ucn 1 and 32 and 26\% with CRF (Lewis et al., 2001). Accumulating evidence, as discussed below, has suggested that Ucn 3 is a critical regulator in energy homeostasis. 


\section{CORTICOTROPHIN-RELEASING FACTOR RECEPTORS}

Two receptors have been identified for CRF: type 1 and type $2 \mathrm{CRF}$ receptors $\left(\mathrm{CRF}_{1}\right.$ and $\left.\mathrm{CRF}_{2}\right)$, and amino acid sequence analysis has shown that the two receptors share approximately $70 \%$ homology (Perrin and Vale, 1999; Bale and Vale, 2004). Both $\mathrm{CRF}_{1}$ and $\mathrm{CRF}_{2}$ are $\mathrm{G}$-protein-coupled receptors with seven transmembrane domains. These receptors signal predominantly through increased cAMP production, but additional signaling pathways including $\mathrm{Ca}^{2+}$, mitogen-activated protein kinase (MAPK), phospholipase $\mathrm{C}$, protein kinase $\mathrm{B}$, and ion channels have also been shown to couple to CRFRs (Kiang, 1997; Grammatopoulos, 2000; Brar et al., 2002). The two receptors differ significantly in their binding affinity for CRF peptides and anatomical distribution within the central nervous system (Chalmers et al., 1995; Van Pett et al., 2000; Hsu and Hsueh, 2001; Lewis et al., 2001). Biochemical studies have shown that $\mathrm{CRF}$ binds $\mathrm{CRF}_{1}$ with high affinity while showing modest affinity for $\mathrm{CRF}_{2}$ (Bale and Vale, 2004). Ucn 1 binds both $\mathrm{CRF}_{1}$ and $\mathrm{CRF}_{2}$ with equally high affinity while $U \mathrm{cn} 2$ and $U \mathrm{cn} 3$ demonstrate preferential specificity for $\mathrm{CRF}_{2}$. However, while $\mathrm{Ucn}$ 2 may bind and stimulate $\mathrm{CRF}_{1}$ at high, pharmacological concentrations (Reyes et al., 2001), Ucn 3 is highly selective to $\mathrm{CRF}_{2}$ and displays minimal affinity for $\mathrm{CRF}_{1}$ (Hsu and Hsueh, 2001; Lewis et al., 2001).

A circulating protein has been identified that binds CRF. It has been suggested that the function of CRF binding protein (CRFBP) is mainly to sequester CRF to reduce its HPA axis stimulation. Levels of CRFBP are elevated in pregnancy to dampen the negative effect of stress responses on the developing fetus (Goland, 1986). In addition to CRFBP, a splice variant of $\mathrm{CRF}_{2}$ has been identified that contains only the extracellular domain of the receptor and shown to circulate, bind, and sequester CRF as well (Bon et al., 1997; Chen et al., 2005). This splice variant also binds Ucn 1 but has very low affinity for Ucn 2 and 3 (Chen et al., 2005).

Anatomical mapping studies have demonstrated that $\mathrm{CRF}_{1}$ and $\mathrm{CRF}_{2}$ have distinct distributions in the brain. $\mathrm{CRF}_{1}$ has a wide distribution throughout the brain with high density in the medial septal area, amygdala, and cerebellum (Chalmers et al., 1995; Van Pett et al., 2000). $\mathrm{CRF}_{2}$ has three major variants that differ in their N-terminal domains: $\mathrm{CRF}_{2(\mathrm{a})}, \mathrm{CRF}_{2(\mathrm{~b})}$, and $\mathrm{CRF}_{2(\mathrm{c})}$. In murine brains, $\mathrm{CRF}_{2 \text { (a) }}$ is predominantly expressed in the hypothalamus, lateral septum (LS), and dorsal raphe (Chalmers et al., 1995; Van Pett et al., 2000). $\mathrm{CRF}_{2(\mathrm{~b})}$ is found predominantly in the periphery, including in skeletal muscle, the gastrointestinal tract, and the heart (Kanno, 1999; Wiley and Davenport, 2004; Porcher et al., 2005; Tache and Bonaz, 2007). $\mathrm{CRF}_{2(\mathrm{c})}$ is found only in the human brain (Kostich et al., 1998).

The function of $\mathrm{CRF}_{1}$ has been closely associated with the stress response, including the release of adrenocorticotropic hormone (ACTH) from the anterior pituitary and behavioral adaptation to stressors (Bale and Vale, 2004). The physiological role of $\mathrm{CRF}_{2}$, however, is less defined. Functional studies have shown this receptor is involved in an array of homeostatic regulations, with most of its actions regulating energy balance by modulating feeding, blood glucose levels, and energy expenditure. This review will focus on recent advances in the understanding of the physiological role of $\mathrm{CRF}_{2}$ and $\mathrm{Ucn} 3$ in the brain, particularly in the hypothalamus, in the regulation of energy balance.

\section{$\mathrm{CRF}_{2}$ IN ENERGY HOMEOSTASIS}

Loss-of-function studies with $\mathrm{CRF}_{2}$ null mice and pharmacological studies with $\mathrm{CRF}_{2}$ agonists both suggest that endogenous $\mathrm{CRF}_{2}$ plays a physiological role in energy balance. Evidence from several studies that examined ingestive behavior of $\mathrm{CRF}_{2}$ null mice showed that endogenous $\mathrm{CRF}_{2}$ is required for the anorectic effect of CRF peptide and is involved in control of the meal size during active phase of eating and following acute exposure to the stress (Bale et al., 2000; Coste et al., 2000; Pelleymounter et al., 2000; Tabarin et al., 2007). Similarly, infusion of antisense oligonucleotides to $\mathrm{CRF}_{2}$ mRNA attenuates both CRF and Ucn 1induced hypophagia and corticosterone secretion (Smagin et al., 1998). Furthermore, $\mathrm{CRF}_{2}$ deletion protects mice from high-fat diet-induced insulin resistance and glucose intolerance (Bale et al., 2003). Taken together, it is clear that $\mathrm{CRF}_{2}$ is responsible for mediating the effect of CRF family peptides on the suppression of feeding and is involved in corticosterone secretion and glucose homeostasis.

In addition to feeding, $\mathrm{CRF}_{2}$ is involved in regulating energy expenditure. $\mathrm{CRF}_{2}$ knockout (KO) mice have more active metabolism and lose heat faster than wildtype (WT) mice (Carlin et al., 2006), suggesting an exaggerated level of sympathetic activity. Moreover, $\mathrm{CRF}_{2} \mathrm{KO}$ mice have higher brown adipose tissue (BAT) temperature and, when given a choice between room temperature and warm areas, prefer warmer areas more than WT mice (Carlin et al., 2006). The KO mice also have higher oxygen consumption and carbon dioxide production and reduced respiratory exchange rate (Carlin et al., 2006), indicating a preference in fatty acid oxidation over carbohydrate utilization in the $\mathrm{KO}$ mice. It was suggested that a lack of functional $\mathrm{CRF}_{2}$ leads to elevated $\mathrm{CRF}_{1}$ activity, which consequently increases sympathetic nervous system (SNS) activity to promote lipolysis (Carlin et al., 2006). This hypothesis appears to disagree with pharmacological studies, as activation of central $\mathrm{CRF}_{2}$ (discussed below), in most cases, results in increased SNS activity. This apparent discrepancy may result from a number of possibilities including compensatory mechanisms due to total body $\mathrm{KO}$ of the receptor as compared to acute, local stimulation of the receptor in the brain. Obviously more studies are needed to further elucidate this issue.

Leptin, a hormone secreted by adipocytes, is a potent appetite suppressant (Uehara et al., 1998; Zigman, 2003). A number of studies suggest that its effect on feeding may involve the CRF receptor system. Though leptin treatment greatly decreases food intake, when co-administered with a non-selective CRF receptor antagonist, food intake remains at a nearly normal level (Gardner etal., 1998), suggesting the CRF system is a downstream target of leptin in the brain. However, this notion was recently challenged by a study (Harris, 2010) demonstrating that $\mathrm{CRF}_{2}$ is not essential for the effects of leptin on energy balance, including feeding and body weight regulation. Again this discrepancy may be due to the nature of global $\mathrm{CRF}_{2} \mathrm{KO}$, which potentially results in functional compensation such as exaggerated $\mathrm{CRF}_{1}$ activity in these mice (Carlin et al., 2006). Therefore, central or specific brain area deletions of $\mathrm{CRF}_{2}$ may be necessary to further evaluate the interaction of leptin and the CRF system in the brain. 


\section{UROCORTIN 3}

\section{ANATOMICAL LOCATION OF Ucn 3}

Urocortin 3 is found both in the periphery and in the brain. In the periphery, it is expressed in the digestive tract, muscle, thyroid and adrenal glands, pancreas, heart, spleen, and skin (Hsu and Hsueh, 2001; Lewis et al., 2001). In the brain, neurons expressing Ucn 3 are concentrated in the medial amygdala (MeA) and hypothalamus (Lewis et al., 2001; Li et al., 2002). In the hypothalamus, the major Ucn 3 cell population is near the rostral perifornical hypothalamic area (rPFA; Li et al., 2002). Specifically, Ucn 3-positive cells are gathered around the fornix lateral to the paraventricular nucleus of the hypothalamus (PVH). This group extends rostrally and stays close to the fornix into the posterior part of the bed nucleus of the stria terminalis (pBNST) and medially into the anterior parvicellular part of the PVH (PVHap). A recent study has elucidated anatomical heterogeneity within this hypothalamic Ucn 3 cell population, as neurons of the rostral part (PVHap/pBNST) project to the ventromedial hypothalamus (VMH), and those of the caudal part, residing in the rostral perifornical hypothalamus ( $\mathrm{rPFH})$, projects to the LS (Chen et al., 2011). A second group of Ucn 3 positive cells is found in the median preoptic nucleus ( $\mathrm{MnPO}$; $\mathrm{Li}$ et al., 2002). In the forebrain, prominent Ucn 3 nerve fibers and terminals are found in the VMH, LS, MeA, and BNST ( $\mathrm{Li}$ et al., 2002). These areas also express high levels of $\mathrm{CRF}_{2}$ (Chalmers et al., 1995; Van Pett et al., 2000). This overlap of Ucn 3 and $\mathrm{CRF}_{2}$ distribution and the high affinity of the peptide for the receptor strongly suggest that $U \mathrm{cn} 3$ is an endogenous ligand for $\mathrm{CRF}_{2}$ in these brain areas.

\section{METABOLIC EFFECTS OF Ucn 3}

All 3 Ucns bind $\mathrm{CRF}_{2}$ and may each be responsible for some of the receptor's energy homeostatic effects. However, Ucn 3 alone has myriad metabolic effects.

\section{Feeding}

Central administration, $\mathrm{KO}$, and overexpression studies reveal a role of Ucn 3 in the regulation of feeding. When directly infused into the lateral ventricles, Ucn 3 decreases nocturnal food and water intake in a dose dependent manner, primarily due to decreased meal frequency, and this effect was eliminated with concomitant $\mathrm{CRF}_{2}$ antagonist treatment (Fekete et al., 2007). The anorectic effect of Ucn 3 is not due to distaste for food, as no concurrent taste aversion develops (Fekete et al., 2007). Consistent with pharmacological evidence, genetic Ucn 3 deficiency appears to lead to overeating. Though Ucn $3 \mathrm{KO}$ mice have similar body weights to WT animals, $\mathrm{KO}$ mice eat more and have increased accumulated food intake. Similar to $\mathrm{CRF}_{2}$ null mice, Ucn $3 \mathrm{KO}$ mice exhibit elevated nocturnal feeding, when greatest spontaneous food intake naturally occurs (Chao et al., 2012). Taken together, it is clear that Ucn 3 in the brain functions as a potent anorectic agent. However, a study that used genetic overexpression of Ucn 3 challenged this notion. Under regular chow-fed condition, mice with overexpression of $\operatorname{Ucn} 3(U c n 3+)$ have higher body mass-adjusted food intake than WT and are heavier than WT controls due to increased lean body mass (Jamieson et al., 2011). On the other hand, Ucn3+ mice do not gain as much weight as WT mice when fed with a high-fat diet (Jamieson et al., 2011). This result seems to be in line with the notion of $U \mathrm{cn} 3$ as an anorectic agent. The discrepancy between different mouse models can be due to a number of possibilities including the ramification of Ucn 3 overexpression both in the brain as well as in the periphery.

A temporally and spatially controlled viral approach to overexpress Ucn 3 in the rPFH shows that Ucn 3 in the rPFH does not modulate food intake (Kuperman et al., 2010), as mice with Ucn 3 overexpression in the $\mathrm{rPFH}$ ingest consume similar amount of food as control mice (Kuperman et al., 2010). The rPFH-specific Ucn 3-overexpressing mice show a trend toward being heavier, but retain the same fat-lean mass percentages as control mice (Kuperman et al., 2010). As mentioned above, Ucn 3 cells in the rPFH project mainly to the LS with minimal projection to the VMH. Therefore, it is reasonable to assume that $\mathrm{CRF}_{2}$ in the LS will be overstimulated in this mouse model. Interestingly, a number of studies have shown that $\mathrm{CRF}_{2}$ in the LS is involved in suppression of food intake (Wang and Kotz, 2002; Bakshi et al., 2007). Currently, it is unclear as to why overexpression of Ucn 3 in the rPFH fails to suppress feeding. The expression of CRF receptor has been shown to be subject to ligand-induced receptor down-regulation (Rabadan-Diehl et al., 1996; Eghbal-Ahmadi et al., 1997). It is conceivable that chronic elevated Ucn 3 input to the LS in Ucn $3 \mathrm{rPFH}$ overexpression mice may lead to alteration in $\mathrm{CRF}_{2}$ expression and consequently reduced response to $U \mathrm{cn} 3$ stimulation in the LS. Thus, it is possible that acute stimulation of $\mathrm{CRF}_{2}$ in the LS suppresses feeding, but chronic stimulation of $\mathrm{CRF}_{2}$ in the LS in mice with Ucn 3 overexpression in the $\mathrm{rPFH}$ may lead to negative feedback to balance the effect of $\mathrm{CRF}_{2}$ in feeding. Clearly, more studies are needed to elucidate the effect of $U$ cn 3 overexpression in the regulation of food intake. In addition to Ucn 3, Ucn 1 neurons in the midbrain Edinger-Westphal nucleus have been shown to innervate the LS (Kozicz et al., 1998; Bittencourt et al., 1999). Therefore, both Ucn 1 and 3 may contribute to the effect of $\mathrm{CRF}_{2}$ on feeding in the LS.

The mechanism of Ucn 3-induced anorexia has not been directly studied. Central administration of $\mathrm{CRF}_{2}$ agonists, including $U c n$ 3, have been shown to inhibit gastric emptying (Martinez et al., 2004; Stengel and Tache, 2009), and elevate blood glucose levels (Jamieson et al., 2006; Chen et al., 2010). Both reduced gut motility and hyperglycemia have been shown to induce satiation and reduce feeding (Ritter, 2004; Cummings and Overduin, 2007; Wolfgang et al., 2007; Cha et al., 2008). Therefore, multiple mechanisms are potentially involved in mediating the anorectic effect of Ucn 3 in the brain.

\section{Energy homeostasis}

Similarly to $\mathrm{CRF}_{2}$, Ucn 3 is also involved in energy expenditure. Central administration of Ucn 3 increases motor activity (Ohata and Shibasaki, 2004). Similarly, transgenic Ucn 3 overexpression mice $(U c n 3+)$ have an increased respiratory exchange ratio and increased motor activity in their home cages (Jamieson et al., 2011). Furthermore, mice with Ucn 3 overexpressed in the rPFH had an increased respiratory exchange ratio and elevated heat production (Kuperman et al., 2010). This is consistent with the notion that Ucn 3 is involved in SNS activity and energy homeostasis. Ucn $3 \mathrm{KO}$ mice, on the other hand, do not show the same pattern; there are no differences in oxygen consumption, heat 
production, or activity levels (Chao et al., 2012). Therefore, KO of Ucn 3 in specific brain areas may provide better insight into the role of specific populations of Ucn 3 cells in the brain in energy expenditure.

\section{Glucose homeostasis}

Several studies have revealed a complex role of Ucn 3 in glucose homeostasis. Though adult Ucn $3 \mathrm{KO}$ mice fed a chow diet show no differences in glucose tolerance and insulin sensitivity compared to WT mice (Li et al., 2007), Ucn 3 KOs have lower basal insulin levels and show a greater rebound in blood glucose levels after the initial hypoglycemia during an insulin tolerance test ( $\mathrm{Li}$ et al., 2007; Chao et al., 2012). Furthermore, under high-fat diet feeding, adult KO mice are more metabolically resilient. The Ucn $3 \mathrm{KO}$ mice have lower plasma insulin and blood glucose concentrations than WT mice, remain sensitive to insulin and do not develop glucose intolerance and liver steatosis with the same frequency of WT mice (Li et al., 2007). Moreover, aged KO mice show better glucose homeostasis than age-matched WT mice (Li et al., 2007). Overall, Ucn 3 deficiency appears to protect the mice from metabolic disorders caused by high-fat feeding. It is noteworthy that $U c n 3$ is expressed in pancreatic $\beta$ cells and has been shown to play a critical role as a local regulator in insulin secretion ( $\mathrm{Li}$ et al., 2003). Thus, it is likely that Ucn 3 in both the brain and in the periphery, especially in the pancreas, contribute to the phenotypes observed in Ucn 3 null mice.

On the other hand, Ucn3+ transgenic mice also appear to be protected against excessive metabolic challenge, having decreased fed and fasting blood glucose levels and increased tolerance to glucose when challenged in a glucose tolerance test (Jamieson et al., 2011). Fasting insulin levels in $U_{c n} 3+$ mice are also lower than that in WT mice, though an insulin tolerance test shows no differences in insulin sensitivity (Jamieson et al., 2011). When challenged with a high-fat diet, Ucn3+ mice fare better than the WT littermates, maintaining normal body weight and low blood glucose levels, but display comparable insulin sensitivity to the WT control mice (Jamieson et al., 2011). Though Ucn3+ mice show improved glucose homeostasis and insulin sensitivity, overexpression of Ucn 3 in the rPFH produces the opposite effect; rPFH Ucn 3-overexpressing mice show reduced insulin sensitivity and increases basal insulin levels, however they show no difference in glucose tolerance (Kuperman et al., 2010).

While genetic KO of Ucn 3 appears to have metabolic protective qualities, the effect of Ucn 3 overexpression is unclear. Full body overexpression of Ucn 3 seems protective, while targeted overexpression within the rPFH appears metabolically detrimental. Interestingly, Ucn3+ mice have lower fasting blood glucose levels and higher energy intake under basal conditions (Jamieson et al., 2011). As stated earlier, $\mathrm{CRF}_{2}$ is expressed abundantly in a number of peripheral tissues including skeletal muscle (Perrin et al., 1995; Stenzel et al., 1995; Wiley and Davenport, 2004; Porcher et al., 2005; Kuperman et al., 2011). Stimulation of muscle $\mathrm{CRF}_{2}$ has been shown to promote thermogenesis (Solinas et al., 2006). Moreover, muscle $\mathrm{CRF}_{2}$ is involved in regulating skeletal muscle mass (Hinkle et al., 2003) and consistent with this notion, Ucn3+ mice have increased muscle mass (Jamieson et al., 2011). Thus, it is conceivable that the improved glucose homeostasis of $U c n 3+$ mice is due, at least in part, to stimulation of muscle $\mathrm{CRF}_{2}$ by ectopic overexpression of Ucn 3 in the periphery.

\section{Thermoregulation}

Functional studies have shown that Ucn 3 is involved in thermoregulation, potentially acting on brown fat. It was found that Ucn 3 induced a significant increase in body temperature, from 37.2 to $38.6^{\circ} \mathrm{C}\left(99.0\right.$ to $\left.101.5^{\circ} \mathrm{F}\right)$, when injected into the lateral ventricles of rats (Telegdy et al., 2006). Temperature gradually decreased after peaking $2 \mathrm{~h}$ after Ucn 3 administration, but remained significantly elevated for a total of $4 \mathrm{~h}$ (Telegdy et al., 2006). Moreover, pretreating animals with $\mathrm{CRF}_{2}$ but not $\mathrm{CRF}_{1}$ antagonists completely blocked Ucn 3-induced hyperthermia, indicating that the pyrogenic action of Ucn 3 is mediated by $\mathrm{CRF}_{2}$ (Telegdy and Adamik, 2008). Noraminophenazone, a cyclooxygenase inhibitor, simultaneously applied with Ucn 3 also prevented the temperature increase and also attenuated the increase when administered 30 min after Ucn 3 treatment (Telegdy et al., 2006). This indicates that the arachidonic acid cascade forming prostaglandin is a downstream target of central Ucn 3 and $\mathrm{CRF}_{2}$ system in thermoregulation. Currently, the brain loci that may mediate the effect of Ucn 3 in body temperature remain elusive. The MnPO is known to be a center for thermoregulation and expresses high concentrations of the prostaglandin receptor EP3 (Morrison et al., 2008). It has been shown that prostaglandins play an important role in the MnPO through EP3 to regulate body temperature (Morrison et al., 2008). Furthermore, the presence of a group of Ucn 3 cells in the MnPO (Li et al., 2002) suggests that $\mathrm{Ucn} 3$ might be involved in MnPO mediates pyrogenic effects.

\section{REGULATION OF Ucn 3 EXPRESSION IN THE BRAIN}

The expression of Ucn 3 in the brain has been determined in a number of stress paradigms and metabolic challenges. It was found that restraint stress rapidly elevates Ucn 3 gene expression in the MeA and that the elevated Ucn 3 mRNA levels return to basal levels $4 \mathrm{~h}$ after the stress (Jamieson et al., 2006). Restraint stress also increases Ucn 3 mRNA levels in the rPFA but with a slower time course compared to that of the MeA (Venihaki et al., 2004; Jamieson et al., 2006). Adrenalectomy greatly elevates Ucn 3 expression in the rPFA, while corticosterone replacement returns the expression to a basal level (Jamieson et al., 2006). This result indicates that corticosterone may be involved in stress-mediated Ucn 3 gene expression in the rPFA. Hemorrhage decreases Ucn 3 expression in the MeA after $30 \mathrm{~min}$, and $48 \mathrm{~h}$ of food deprivation also decreases Ucn 3 expression in the MeA (Jamieson et al., 2006).

The expression of Ucn 3 has also been examined in genetically obese rodent models. Food deprivation increases Ucn 3 mRNA expression in the dorsal part of the medial amygdala $(\mathrm{MeD})$ in obese $\mathrm{Fa} / \mathrm{Fa}$ Zuker rats and has no effect on Ucn 3 expression in the rPFH (Poulin et al., 2012). In contrast, lean Fa/? rats show increased Ucn 3 expression in the rPFH but not the MeD after food deprivation (Poulin et al., 2012). Ucn 3 mRNA expression returns to normal after $24 \mathrm{~h}$ of refeeding (Poulin et al., 2012). In ob/ob obese mice, Ucn 3 expression is significantly reduced in the MeA (Figure 1; Li and Vale, 2002), and leptin treatment reverses Ucn 3 expression in this area. Interestingly, pair-feeding in ob/ob mice 

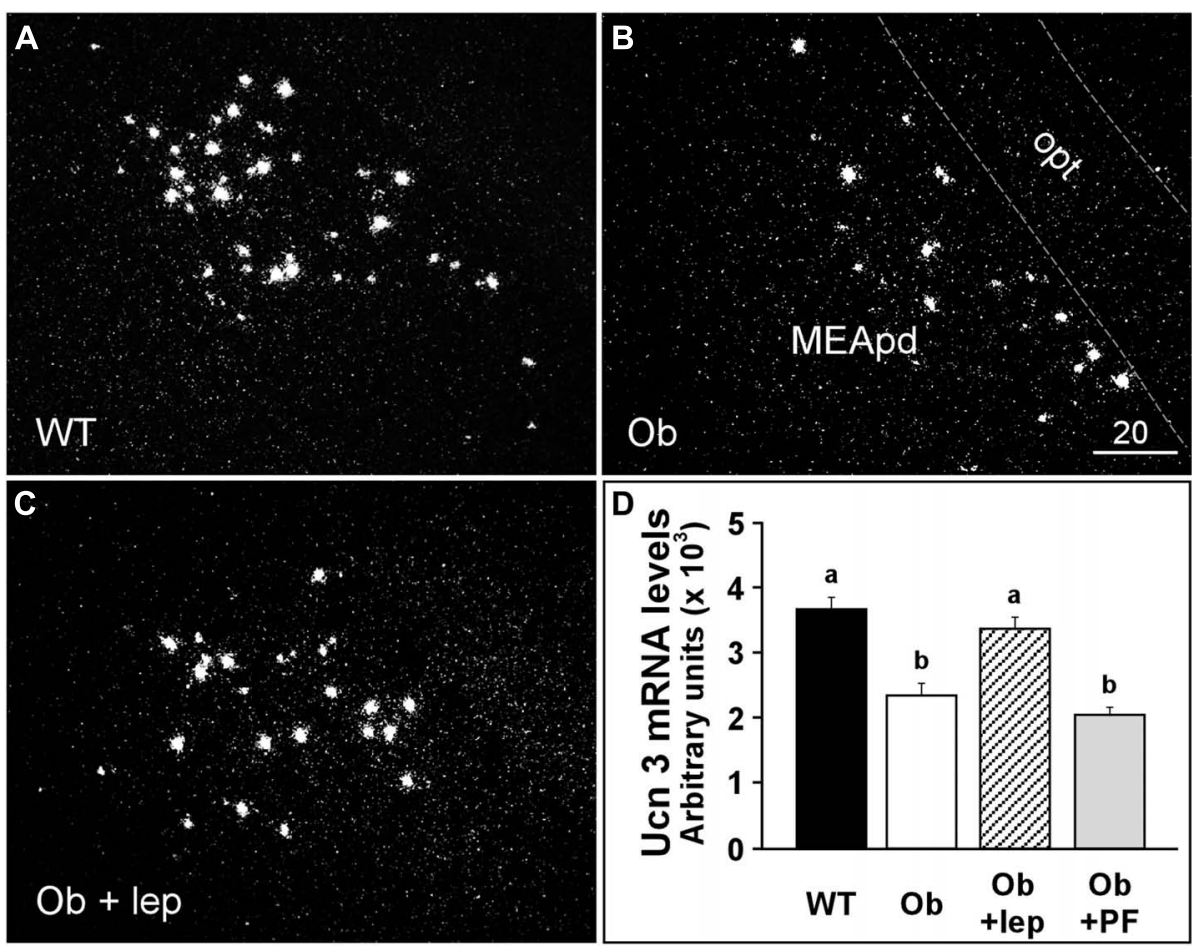

FIGURE 1 | Representative darkfield photomicrographs showing Ucn 3 mRNA expression (white clusters) in a wildtype mouse (A), an ob/ob obese mouse (B), and an ob/ob mouse treated with leptin $\mathbf{( 0 . 1} \mathbf{~ m g / k g / d a y ~ f o r ~} \mathbf{2}$ days) (C). (D) Summary of Ucn 3 mRNA levels in the MeA of WT and Ob/ob obese mice treated with vehicle or leptin. The Ucn 3 mRNA levels in an additional group of Ob/ob mice that was paired-fed were also determined. Different letters represent statistical significance: $p<0.05$. MeApd, medial nucleus of amygdala, posterodorsal part; opt, optic tract. Scale bar $=20 \mu \mathrm{m}$ failed to modulate Ucn 3 expression in the MeA. These results indicate that Ucn 3 expression in the MeA is regulated by leptin. Taken together, these studies further support the notion that endogenous Ucn 3 in the brain is sensitive to metabolic signals and energy status and potentially plays an important role in regulating energy homeostasis.

\section{THE VENTROMEDIAL HYPOTHALAMUS}

The anatomical distribution of $\mathrm{CRF}_{2}$ in the brain has provided important insight into possible areas that mediate the effects of $\mathrm{CRF}_{2}$ in energy balance. The VMH has received significant attention due to its abundant expression of $\mathrm{CRF}_{2}$ and well-known role in regulating energy homeostasis, feeding, and blood glucose levels.

The VMH is parceled on cytoarchitectonic grounds into three major divisions: dorsomedial (VMHdm), central, and the ventrolateral (VMHvl) parts (Gurdjian, 1927). The VMH volume is larger in males compared with females, and this difference is largely accounted for by the VMHvl, which in females is significantly smaller than that in males (Dugger et al., 2007). Further, $\mathrm{VMHvl}$ in female rats express higher levels of estrogen receptors than that in males, and has been shown to play a critical role in regulating lordosis behavior in females (Flanagan-Cato, 2011) and aggressiveness in males (Lin et al., 2011).

The VMH has long been considered a critical brain area in the regulation of energy homeostasis. Lesion of the VMH results in hyperphagia, hyperinsulinemia, reduction of SNS activity, increase of fat mass, and reduction of energy expenditure that ultimately leads to storage of excess of energy and obesity (Bernardis and Frohman, 1971; Inoue et al., 1977; Cox and Powley, 1981; Niijima et al., 1984; Sakaguchi et al., 1988; Ruffin and Nicolaidis, 1999; King, 2006). Conversely, stimulation of the VMH results in predominately opposite phenotypes including induction of satiety, increase in SNS activity, lipolysis, and thermogenesis (King, 2006). In recent years, the importance of the $\mathrm{VMH}$ in energy homeostasis has been further ascertained with the aid of improved molecular tools and mouse genetics (Sternson et al., 2005; King, 2006; Chao et al., 2012). For example, mice with VMH-specific deletion of a number of genes including the leptin receptor (Dhillon et al., 2006; Bingham et al., 2008), estrogen receptor $\alpha$ (Musatov et al., 2006, 2007), and vesicular glutamate transporter-2 (VGLUT2; Tong et al., 2007) result in a number of abnormalities such as increased feeding, reduced energy expenditure, impaired glucose homeostatic regulation, and obesity. Moreover, mice bearing a deletion of steroidogenic factor 1 (SF1), a transcription factor involved in steroidogenesis that is highly enriched in the $\mathrm{VMH}$, show similar phenotypes in energy homeostasis and are obese (Luo et al., 1994; Sadovsky et al., 1995; Shinoda et al., 1995).

\section{EXPRESSION OF CRF 2 IN THE VMH}

The $\mathrm{VMH}$ is one of the brain areas with prominent $\mathrm{CRF}_{2}$ expression (Chalmers et al., 1995; Van Pett et al., 2000). The expression is 
concentrated in the dorsomedial part of the nucleus with decreasing density toward the ventrolateral division of the $\mathrm{VMH}$. The expression of $\mathrm{CRF}_{2}$ in the $\mathrm{VMH}$ has been shown to be sensitive to energy status and stress. For example, leptin injection increases and fasting decreases $\mathrm{CRF}_{2}$ expression in the $\mathrm{VMH}$ and ob/ob mice or $\mathrm{Fa} / \mathrm{Fa}$ Zucker rats have lower $\mathrm{CRF}_{2}$ in the $\mathrm{VMH}$ compared to WT controls (Richard et al., 1996; Makino et al., 1998, 1999; Nishiyama et al., 1999). Furthermore, restraint stress and glucocorticoids increase $\mathrm{CRF}_{2}$ levels in the VMH (Makino et al., 1998, 1999). Thus, these data support the notion that $\mathrm{CRF}_{2}$ in the VMH is important in regulating energy balance.

Currently, detailed neurochemical phenotypes of $\mathrm{CRF}_{2}-$ positive cells within the $\mathrm{VMH}$ remain unclear. Several proteins have been found to be expressed in the VMH including SF1, pituitary adenylate cyclase-activating polypeptide, the leptin receptor, and VGLUT2 (Fei et al., 1997; Elmquist et al., 1998; Ziegler et al., 2002; Segal et al., 2005; Kurrasch et al., 2007). It has been shown that $\mathrm{CRF}_{2}$ extensively colocalizes with VGLUT2 in the VMH (Chen et al., 2010). VGLUT2 mediates glutamate uptake into synaptic vesicles of excitatory neurons (Fremeau et al., 2001; Herzog et al., 2001; Takamori et al., 2001) and has been used extensively as a marker for excitatory glutamatergic neurons. The colocalization of $\mathrm{CRF}_{2}$ and VGLUT2 suggests that $\mathrm{CRF}_{2}$ is expressed predominately in excitatory neurons in the VMH. As mentioned above, SF1 is a nuclear receptor that regulates the transcription of key genes involved in sexual development and reproduction (Parker et al., 2002). In adults, SF1 expression is specifically confined to the VMH (Parker et al., 2002). In SF1 null mice, $\mathrm{CRF}_{2}$ mRNA expression is nearly undetectable in the VMH (Luo et al., 1994; Sadovsky et al., 1995; Shinoda et al., 1995), suggesting $\mathrm{CRF}_{2}$ is expressed in SF1 cells in the VMH. Consistent with this notion, it was found that more than $90 \%$ of $\mathrm{CRF}_{2}$ neurons in the dorsomedial part of the nucleus are also SF1-positive (Figure 2) with less colocalization of these two materials in the VMHvl (Digruccio et al., 2007).

\section{CRF LIGANDS INPUT INTO THE VMH}

The anatomical distribution of a number of the CRF family peptides has been determined, and it was found that CRF and Ucn 1-expressing neurons provide minor innervation to the $\mathrm{VMH}$ (Swanson et al., 1983; Kozicz et al., 1998; Bittencourt et al., 1999). Interestingly, low levels of Ucn 1-immunoreactivity have been detected in cells in the VMH (Kozicz et al., 1998), suggesting Ucn 1 may be a local factor in the nucleus. Although Ucn 2 fiber distribution has not been determined, Ucn 2-positive cells have been found in a number of brain areas including the magnocellular part of the PVH, locus ceruleus, and facial motor nucleus (Reyes et al., 2001), and none of these areas provide extensive projection into the VMH (McBride and Sutin, 1977; Luiten and Room, 1980; Berk and Finkelstein, 1981; Kita and Oomura, 1982; Zaborszky, 1982; Fahrbach et al., 1989; Chen et al., 2011). Compared to other CRF innervations, Ucn 3 neuronal fibers abundantly innervate the VMH (Li et al., 2002). Similar to the expression of $\mathrm{CRF}_{2}$ in the VMH, Ucn 3-positive axonal fibers and terminals concentrate in the dorsomedial part of the VMH with reduced density toward the ventrolateral part of the nucleus (Li et al., 2002). As stated above, Ucn 3 neurons in the PVHap provide the major Ucn 3 afferent input into the VMH and Ucn 3 cells in the pBNST and

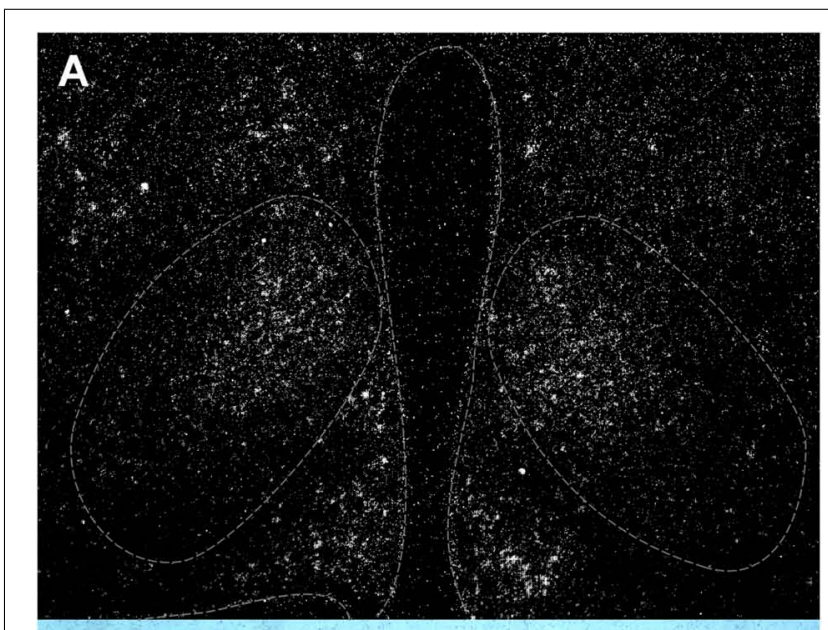

B

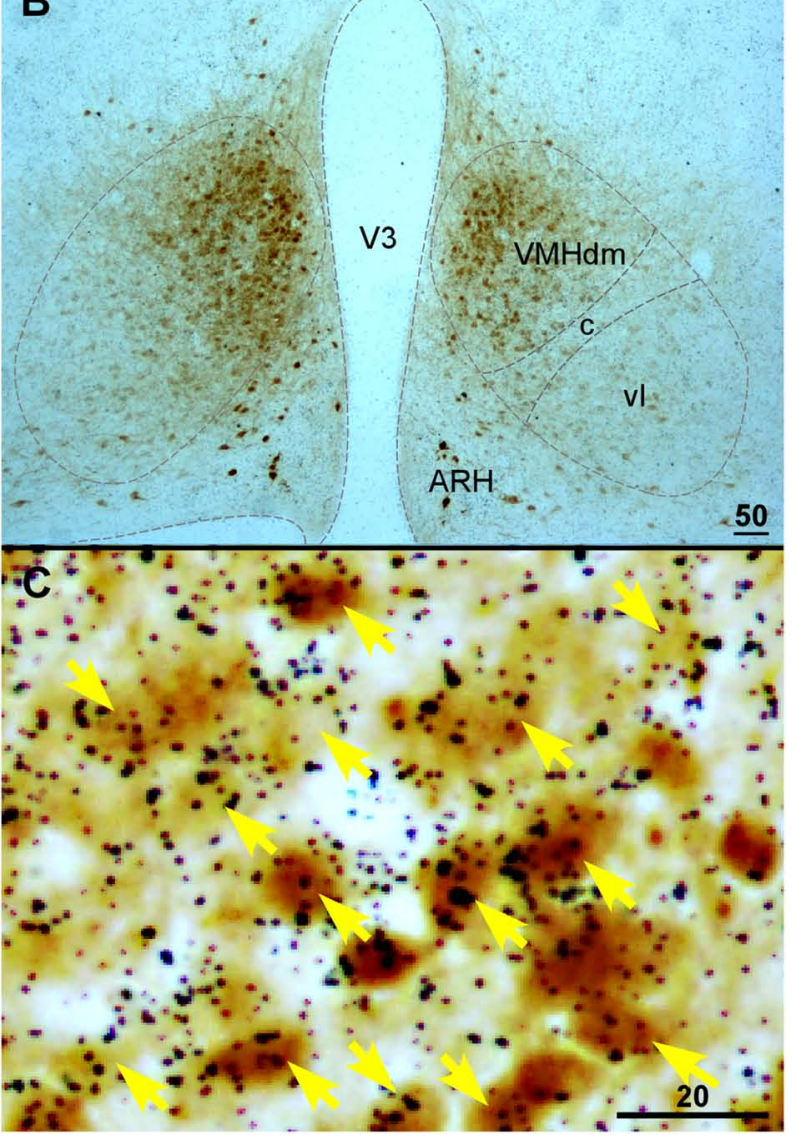

FIGURE 2 | (A) Darkfield photomicrograph showing CRFR2 mRNA signal revealed by in situ hybridization in the basal hypothalamic area of a transgenic mouse expressing Cre recombinase (Cre) and enhanced yellow fluorescent protein (EYFP) in SF1-positive cells. Note that CRFR2 mRNA hybridization signal (white clusters) was abundant in the dorsomedial part of the VMH (VMHdm). (B) Bright field photomicrograph of the same area in (A) showing SF1-positive cells, revealed by immunostaining with anti-green fluorescent protein antibody (darkbrown precipitates) in the VMH. (C) High magnification of boxed area in (A) showing colocalization of CRFR2 (black dot clusters) and SF1 (brown precipitates) in the VMH. ARH, arcuate nucleus of hypothalamus; $\mathrm{V} 3$, third ventricle; $\mathrm{VMHc}$, central part of the $\mathrm{VMH}$; VMHdm, dorsomedial part of the $\mathrm{VMH} ; \mathrm{VMHvl}$, ventrolateral part of the $\mathrm{VMH}$. Scale bar $=50 \mu \mathrm{m}$ (B), $20 \mu \mathrm{m}$ (C). 
the MeA comparatively provide moderate input into the nucleus (Chen et al., 2011). Interestingly, Ucn 3 cells in the rPFH, immediately caudal and adjacent to the PVHap, provide minimal Ucn 3 afferent input into the $\mathrm{VMH}$ and instead send strong innervation into the LS.

Neural inputs into the PVHap and MeA have been studied (Sawchenko and Swanson, 1983; Swanson and Petrovich, 1998; Uehara et al., 1998; Maras and Petrulis, 2010; Carrillo et al., 2011; Northcutt and Lonstein, 2011; Radley and Sawchenko, 2011; Van Hover et al., 2011). In general, the two brain areas receive similar afferent input from a number of brain regions including the septal nuclei and amygdala. However, a few subtle but significant exceptions should be noted. The PVHap receives prominent inputs from the hypothalamus, cortex, and brainstem, whereas the MeA receives strong inputs from the bed nucleus of the accessory olfactory tract and nucleus of stria medullaris. These findings suggest Ucn 3 cells in the PVHap receive inputs that transmit visceral and autonomic information while the Ucn 3 cell group in the MeA receives afferents that relay olfactory information. Thus, it is conceivable that central Ucn 3 may serve as a common peptide neurotransmitter in the various neural pathways that convey information from assorted neural signals into the $\mathrm{VMH}$ to coordinate the regulation of energy homeostasis.

\section{FUNCTION OF CRF 2 IN THE VMH}

When the function of $\mathrm{CRF}_{2}$ in the $\mathrm{VMH}$ was first assessed by injecting Ucn 1 into the $\mathrm{VMH}$, it was found that the peptide potently suppresses food intake (Ohata et al., 2000). However, because $\mathrm{CRF}_{1}$ has been suggested to be expressed in the VMH (Cheng et al., 2007) and Ucn 1 has equally high affinity for both $\mathrm{CRF}_{1}$ and $\mathrm{CRF}_{2}$ (Vaughan et al., 1995), it remains possible that $\mathrm{CRF}_{1}$ may also contribute to the anorectic effect of Ucn 1 in the VMH. More recently, when the $\mathrm{CRF}_{2}$-selective ligand $\mathrm{Ucn} 3$ was identified (Lewis et al., 2001), the function of $\mathrm{CRF}_{2}$ in the $\mathrm{VMH}$ was re-examined by site-specific injection of Ucn 3 into the VMH (Fekete et al., 2007; Chen et al., 2010). Consistent with the Ucn 1 injection study, stimulation of $\mathrm{CRF}_{2}$ by $\mathrm{Ucn} 3$ in the $\mathrm{VMH}$ significantly suppresses feeding. Moreover, stimulation of $\mathrm{CRF}_{2}$ in other regions including the $\mathrm{PVH}$, amygdala, and the lateral hypothalamus fails to modulate feeding (Ohata et al., 2000; Fekete et al., 2007; Chen et al., 2010), reinforcing the notion that $\mathrm{VMH} \mathrm{CRF}_{2}$ plays a critical role in mediating the effect of CRF peptides in suppressing food intake.

In addition to appetite suppression, activation of $\mathrm{CRF}_{2}$ in the VMH results in rapid elevation of blood glucose levels (Chen et al., 2010). This is consistent with the function of VMH neurons in glucose homeostasis, as VMH neurons have been suggested to play an important role in regulating glucose levels via glucose sensing, and modulating glucose production in peripheral tissues (Kang et al., 2004; Levin et al., 2004). On the other hand, it has been shown that stimulation of $\mathrm{CRF}_{2}$ in the $\mathrm{VMH}$ suppresses insulininduced release of glucagon and epinephrine (McCrimmon et al., 2006), indicating that $\mathrm{VMH} \mathrm{CRF}_{2}$ exerts a negative control over the counterregulatory response (CRR). Taken together, it is possible that the functional role of $\mathrm{CRF}_{2}$ in the VMH in glucose homeostasis is context dependent. When blood glucose is low as a result of hyperinsulinemia, $\mathrm{CRF}_{2}$ in the $\mathrm{VMH}$ negatively regulates the
CRR response. On the other hand, under normoglycemia, $\mathrm{CRF}_{2}$ induces acute hyperglycemia to facilitate fuel mobilization perhaps in response to stress. We have also found that $\mathrm{CRF}_{2}$-positive neurons in the VMH are sensitive to glucose, as high glucose inhibits and low glucose stimulates the neuronal activity (Digruccio et al., 2007).

Type 2 CRF receptor has been shown to modulate the HPA axis. For example, $\mathrm{CRF}_{2} \mathrm{KO}$ mice display altered HPA hormonal secretion, and central Ucn 3 injection facilitates stress-induced ACTH secretion (Jamieson et al., 2006). On the other hand, activation of $\mathrm{CRF}_{2}$ in the $\mathrm{VMH}$ fails to modulate HPA hormone secretion (Chen et al., 2010), indicating that the receptor in the VMH is not essential for central Ucn 3-induced HPA activation. Thus, $\mathrm{CRF}_{2}$ positive brain loci that are important for modulation of the HPA axis remain to be determined.

\section{PHYSIOLOGICAL ROLE OF CRF 2 IN THE VMH}

To probe the physiological role of endogenous $\mathrm{CRF}_{2}$ in the $\mathrm{VMH}$, $\mathrm{VMH}$-specific $\mathrm{CRF}_{2}$ knockdown mice were generated by injection of a lentiviral vector expressing $\mathrm{CRF}_{2}$ small hairpin RNA (shRNA; Chao et al., 2012). Mice injected with $\mathrm{CRF}_{2}$ shRNA displayed significantly reduced $\mathrm{CRF}_{2}$ mRNA levels and gain more weight, mostly in white fat, than control mice. Furthermore, similar to Ucn 3 null mice, mice with reduced CRFR2 in the VMH exhibited elevated basal food intake and ate more than the control mice after overnight fasting. This result indicates that $\mathrm{CRF}_{2}$ in the VMH serves as a brake to facilitate the cessation of feeding. This study suggests that $\mathrm{CRF}_{2}$ in the VMH plays a critical role in mediating the effect of central Ucn 3 in energy balance.

In addition to elevated feeding, mice with decreased expression of $\mathrm{CRF}_{2}$ in the VMH display reduced lipolysis and increased adiposity in white fat (Chao etal., 2012). This is likely due to reduced SNS activity, as the VMH has been shown to regulate lipolysis via sympathetic outflow (Kumon et al., 1976; Takahashi and Shimazu, 1981; Ruffin and Nicolaidis, 1999). Interestingly, $\mathrm{CRF}_{2}$ knockdown in the $\mathrm{VMH}$ has no major impact in heat production or uncoupling protein 1 expression in BAT, suggesting that $\mathrm{CRF}_{2}$ in the VMH does not significantly modulate thermogenesis in BAT. This result appears to disagree with earlier reports that $\mathrm{VMH}$ is involved in regulating thermogenesis in BAT (Perkins et al., 1981; Kim et al., 2011). Anatomical studies have demonstrated a compartment-specific organization of innervation of different peripheral organs, as abdominal fat and subcutaneous fat are innervated by different neural pathways (Kreier et al., 2002, 2006). It is possible that $\mathrm{CRF}_{2}$-positive neurons are a subpopulation of cells in the VMH that regulate SNS outflow to white fat without significant functional impact on BAT. Heterogeneity of VMH neurons has been reported as overlapping but distinct subpopulation of neurons in the $\mathrm{VMHvl}$ that are critical in regulating fighting and mating (Lin et al., 2011).

Consistent with the function of $\mathrm{CRF}_{2}$ in regulating blood glucose levels, mice with reduced $\mathrm{CRF}_{2}$ expression in the $\mathrm{VMH}$ show improved glucose homeostasis compared to control mice (Chao et al., 2012). Moreover, mice with $\mathrm{CRF}_{2}$ knocked down in the VMH exhibit an exaggerated rebound in blood glucose levels compared to control mice after the initial hypoglycemic response to insulin challenge. This result agrees with the study by McCrimmon et al. 
(2006), who found that injection of Ucn 3 into the VMH suppresses the hypoglycemia-induced CRR response. Taken together, these studies strongly argue that $\mathrm{CRF}_{2}$ is a critical molecular mediator in $\mathrm{VMH}$ regulation of glucose homeostasis.

\section{NEUROCIRCUITS UNDERLYING THE EFFECT OF VMH}

To understand how $\mathrm{VMH} \mathrm{CRF}_{2}$ neurons regulate output functions and to describe an anatomical link between these neurons and the SNS, it is necessary to determine their axonal projections to identify downstream targets in the brain. A number of anterograde tracing studies utilizing different tracers have been performed to evaluate the projections of VMH neurons. Generally, it was found that $\mathrm{VMH}$ neurons project extensively to neighboring hypothalamic nuclei including the anterior and paraventricular nucleus, BNST, and periaqueductal gray (PAG; Saper et al., 1976; Canteras et al., 1994). These anatomical studies raise an interesting dilemma. Although it is clear that VMH activity modulates SNS activity, these studies failed to observe direct VMH efferents within well-known autonomic centers in the brainstem. Thus, it was concluded that the VMH likely modulates SNS activity indirectly by first projecting to a relay center such as the PAG.

Recently, using a conditional viral tracing approach, we have found that VMH neurons project to a number of important brainstem autonomic centers including the parabrachial nucleus, $\mathrm{C} 1$ catecholaminergic cell group in the rostral ventrolateral medulla, and the nucleus of solitary tract (Lindberg et al., 2011). Moreover, we have used the same approach to find that $\mathrm{CRF}_{2}$-positive cells in the VMH show similar axonal projections to these brainstem areas (Figure 3; Lindberg et al., 2011). These studies demonstrate that VMH neurons, including cells that express $\mathrm{CRF}_{2}$, can potentially modulate SNS activity by direct projections to brainstem autonomic centers.

\section{CONCLUSION}

The function of CRF peptides and their receptors in coordinating hormonal, neuronal, and behavioral responses to stress is well recognized. Pharmacological studies have determined that the $\mathrm{CRF}_{2}$ receptors are involved in the regulation of energy homeostasis. Recent studies using various genetic mouse models and molecular tools have further ascertained the critical role of $\mathrm{CRF}_{2}$ and its selective ligands, including Ucn 3 , in feeding, blood glucose regulation, $\mathrm{SNS}$ output, and peripheral metabolism. Moreover, $\mathrm{CRF}_{2}$ in the VMH mediates most, if not all, of the effects of central Ucn 3 on energy homeostasis.

It is clear that conflicting results have been observed between whole body and region- or tissue-specific $\mathrm{KO}$ or overexpression mouse models. Furthermore, several studies have demonstrated that anatomical or even functional heterogeneity exists within a seemingly single Ucn 3 cell population in the hypothalamus. Thus, a more detailed understanding of the physiological function of $\mathrm{CRF}_{2}$ and its selective ligands in the brain will be aided by brain region-specific transgenic animal models permitting manipulation of ligand or receptor expression. Study of such models will provide insight into the specific roles of $\mathrm{CRF}_{2}$ in modulating metabolic functions.

Regulation of energy balance under diverse challenges including stress, starvation, or high-fat diet requires numerous adaptive
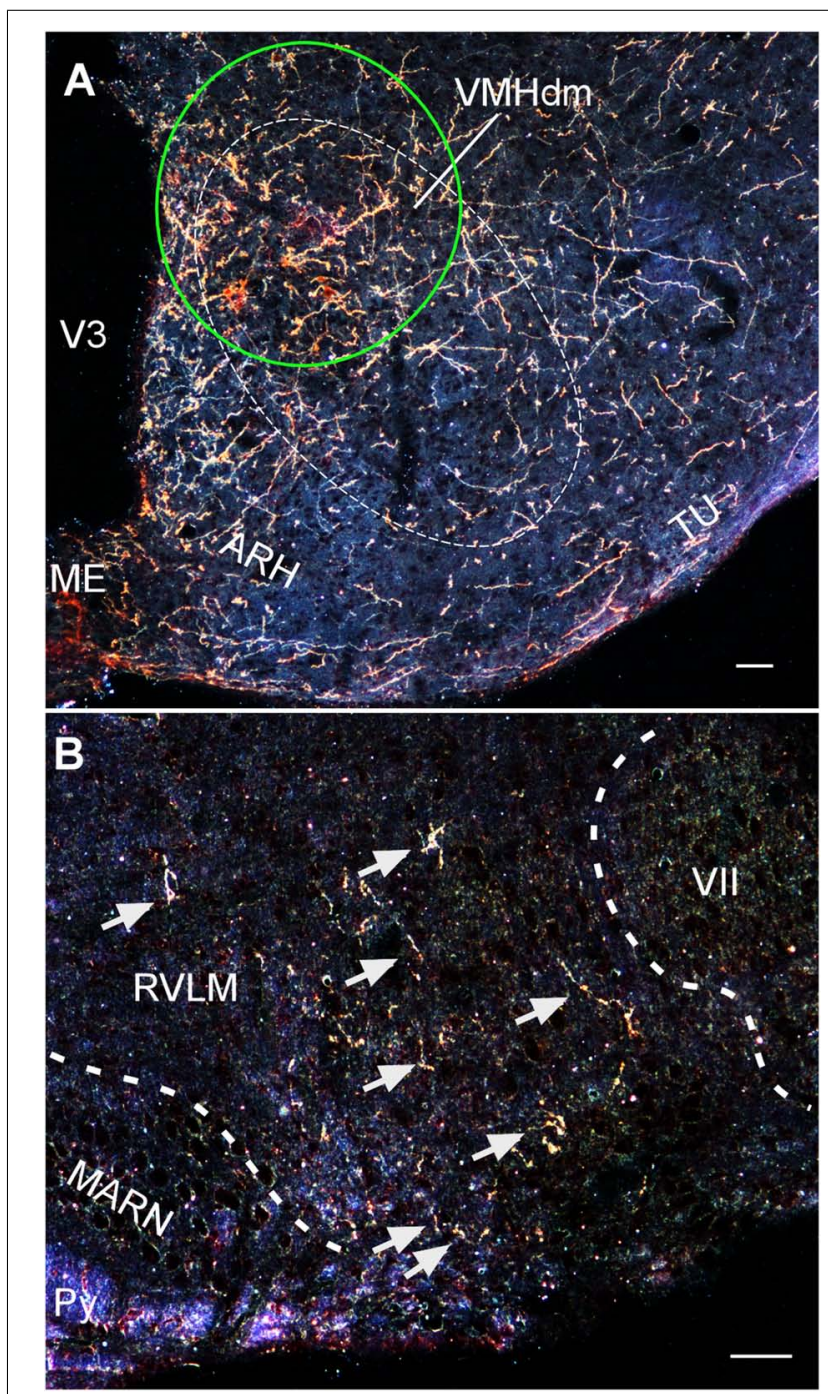

FIGURE 3 | (A) Darkfield photomicrograph showing the injection site (green circle) of an adenoviral vector encoding Cre-regulated expression of farnesylated green fluorescent protein $\left(G P_{f}\right)$ delivered into the $\mathrm{VMH}$ of a CRFR2-Cre mouse. The expression of GFP $_{f}$ is normally silenced due to a Cre-regulated transcription block sequence inserted upstream of $\mathrm{GFP}_{f}$ reporter cassette. In the presence of Cre, the transcription block sequence

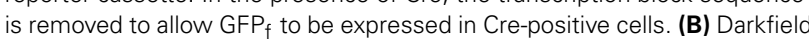
photomicrograph depicting the distribution of VMH CRFR2-positive fibers (golden staining) within the rostral ventrolateral medulla (RVLM). ARH, arcuate nucleus of hypothalamus; MARN, magnocellular reticular nucleus; $\mathrm{ME}$, median eminence; Py, pyramidal tract; Tu, tuberal nucleus; V3, third ventricle; VII, facial nucleus; VMHdn, dorsomedial part of the ventromedial nucleus of hypothalamus. Scale bar $=50 \mu \mathrm{m}$

mechanisms in both central and peripheral tissues. It is now clear that central $\mathrm{CRF}_{2}$ and $\mathrm{Ucn} 3$ are involved in this regulation, as the expression of the receptor and ligands are closely regulated under these challenges. It is thus conceivable that dysregulated $\mathrm{CRF}_{2}$ or ligand function potentially cause or exacerbate metabolic perturbations. This hypothesis can be easily tested with the above mentioned rodent models to determine the functional role of the $\mathrm{CRF}_{2}$ system in metabolic diseases. Moreover, a better understanding of the molecular mechanisms by which various 
stressors or metabolic signals regulate the expression and/or function of $\mathrm{CRF}_{2}$ and its ligand will provide significant insight into the potential role of the CRF family and its receptors in the pathophysiology of metabolic disorders including obesity and diabetes.

\section{REFERENCES}

Bakshi, V. P., Newman, S. M., SmithRoe, S., Jochman, K. A., and Kalin, N. H. (2007). Stimulation of lateral septum CRF2 receptors promotes anorexia and stress-like behaviors: functional homology to CRF1 receptors in basolateral amygdala. J. Neurosci. 27, 10568-10577.

Bale, T. L., Anderson, K. R., Roberts, A. J., Lee, K. F., Nagy, T. R., and Vale, W. (2003). Corticotropin-Releasing factor receptor-2-deficient mice display abnormal homeostatic responses to challenges of increased dietary fat and cold. Endocrinology 144, 25802587.

Bale, T. L., Contarino, A., Smith, G. W., Chan, R. K. W., Gold, L. H., Sawchenko, P. E., et al. (2000). Mice deficient for corticotropin-releasing hormone receptor-2 display anxietylike behavior and are hypersensitive to stress. Nat. Genet. 24, 410-414.

Bale, T. L., Hoshijima, M., Gu, Y., Dalton, N., Anderson, K. R., Lee, K. F., et al. (2004). The cardiovascular physiologic actions of urocortin II: acute effects in murine heart failure. Proc. Natl. Acad. Sci. U.S.A. 101, 3697-3702.

Bale, T. L., and Vale, W. W. (2004). CRF and CRF receptors: role in stress responsivity and other behaviors. Annu. Rev. Pharmacol. Toxicol. 44, 525-557.

Berk, M. L., and Finkelstein, J. A. (1981). Afferent projections to the preoptic area and hypothalamic regions in the rat brain. Neuroscience 6, 1601-1624.

Bernardis, L. L., and Frohman, L. A. (1971). Effects of hypothalamic lesions at different loci on development of hyperinsulinemia and obesity in the weanling rat. J. Comp. Neurol. 141, 107-115.

Bingham, N. C., Anderson, K. K., Reuter, A. L., Stallings, N. R., and Parker, K. L. (2008). Selective loss of leptin receptors in the ventromedial hypothalamic nucleus results in increased adiposity and a metabolic syndrome. Endocrinology 149, 21382148.

Bittencourt, J. C., Vaughan, J., Arias, C., Rissman, R. A., Vale, W. W., and Sawchenko, P. E. (1999). Urocortin expression in rat brain: evidence against a pervasive relationship of urocortin-containing projections with targets bearing type 2 285-312.

Bon, K., Lanteri-Minet, M., De Pommery, J., Michiels, J. F., and Menetrey, D. (1997). Cyclophosphamide cystitis as a model of visceral pain in rats: minor effects at mesodiencephalic levels as revealed by the expression of c-fos, with a note on Krox-24. Exp. Brain Res. 113, 249-264.

Brar, B. K., Stephanou, A., Knight, R. and Latchman, D. S. (2002). Activation of protein kinase B/Akt by urocortin is essential for its ability to protect cardiac cells against hypoxia/reoxygenation-induced cell death. J. Mol. Cell. Cardiol. 34, 483-492.

Breu, J., Touma, C., Hölter, S. M., Knapman, A., Wurst, W., and Deussing, J. M. (2012). Urocortin 2 modulates aspects of social behaviour in mice. Behav. Brain Res. 233, 331-336.

Canteras, N. S., Simerly, R. B., and Swanson, L. W. (1994). Organization of projections from the ventromedial nucleus of the hypothalamus: a Phaseolus vulgaris-leucoagglutinin study in the rat. J. Comp. Neurol. 348, 41-79.

Carlin, K. M., Vale, W. W., and Bale, T. L. (2006). Vital functions of corticotropin-releasing factor (CRF) pathways in maintenance and regulation of energy homeostasis. Proc. Natl. Acad. Sci. U.S.A. 103, 3462 3467.

Carrillo, M., Ricci, L. A., and Melloni, R. H. (2011). Glutamate and the aggression neural circuit in adolescent anabolic steroid-treated Syrian hamsters (Mesocricetus auratus). Behav. Neurosci. 125, 753-763.

Cha, S. H., Wolfgang, M., Tokutake, Y., Chohnan, S., and Lane, M. D. (2008). Differential effects of central fructose and glucose on hypothalamic malonyl-CoA and food intake. Proc. Natl. Acad. Sci. U.S.A. 105, 16871-16875.

Chalmers, D. T., Lovenberg, T. W., and De Souza, E. B. (1995). Localization of novel corticotropin-releasing factor receptor (CRF2) mRNA expression to specific subcortical nuclei in rat brain: comparison with CRF1 receptor mRNA expression. J. Neurosci. 15, 6340-6350.

Chao, H., Digruccio, M., Chen, P., and Li, C. (2012). Type 2 corticotropinreleasing factor receptor in the
CRF receptors. J. Comp. Neurol. 415,

\section{ACKNOWLEDGMENTS}

We thank Dr. Ruth Stornetta for providing comments on the manuscript. This work was supported by the National Institute of Diabetes and Digestive and Kidney Diseases Grant R01 DK-078049 (to Chien Li).

ventromedial nucleus of hypothalamus is critical in regulating feeding and lipid metabolism in white adipose tissue. Endocrinology 153, 166-176.

Chen, A., Brar, B., Choi, C. S., Rousso, D., Vaughan, J., Kuperman, Y., et al. (2006). Urocortin 2 modulates glucose utilization and insulin sensitivity in skeletal muscle. Proc. Natl. Acad. Sci. U.S.A. 103, 16580-16585.

Chen, A. M., Perrin, M. H., Digruccio, M. R., Vaughan, J. M., Brar, B. K., Arias, C. M., et al. (2005). A soluble mouse brain splice variant of type 2alpha corticotropin-releasing factor (CRF) receptor binds ligands and modulates their activity. Proc. Natl. Acad. Sci. U.S.A. 102, 2620-2625

Chen, P., Lin, D., Giesler, J., and Li, C. (2011). Identification of urocortin 3 afferent projection to the ventromedial nucleus of the hypothalamus in rat brain. J. Comp. Neurol. 519, 2023-2042.

Chen, P., Vaughan, J., Donaldson, C., Vale, W. W., and Li, C. (2010). Injection of Urocortin 3 into the ventromedial hypothalamus modulates feeding, blood glucose levels and hypothalamic POMC gene expression but not the HPA axis. Am. J. Physiol. Endocrinol. Metab. 298, E337-E345.

Cheng, H., Zhou, L., Zhu, W. Wang, A., Tang, C., Chan, O., et al. (2007). Type 1 corticotropinreleasing factor receptors in the ventromedial hypothalamus promote hypoglycemia-induced hormonal counterregulation. Am. J. Physiol. Endocrinol. Metab. 293, E705-E712.

Coste, S. C., Kesterson, R. A., Heldwein, K. A., Stevens, S. L., Heard, A. D. Hollis, J. H., et al. (2000). Abnormal adaptations to stress and impaired cardiovascular function in mice lacking corticotropin-releasing hormone receptor-2. Nat. Genet. 24, 403-409.

Cox, J. E., and Powley, T. L. (1981). Prior vagotomy blocks VMH obesity in pair-fed rats. Am. J. Physiol. 240, E573-E583.

Cummings, D. E., and Overduin, J. (2007). Gastrointestinal regulation of food intake. J. Clin. Invest. 117, 13-23.

Dhillon, H., Zigman, J. M., Ye, C., Lee, C. E., Mcgovern, R. A., Tang, V., et al. (2006). Leptin directly activates SF1 neurons in the $\mathrm{VMH}$, and this action by leptin is required for normal body-weight homeostasis. Neuron 49 , 191-203.

Digruccio, M., Chen, P., Cheng, J., Moenter, S., and Li, C. (2007). Generation of transgenic mice expression Cre recombinase in type 2 corticotropin-releasing factor receptor (CRFR2) neurons in the brain. Soc. Neurosci. Abstr. 198, 111.

Dugger, B. N., Morris, J. A., Jordan, C. L., and Breedlove, S. M. (2007). Androgen receptors are required for full masculinization of the ventromedial hypothalamus (VMH) in rats. Horm. Behav. 51, 195-201.

Eghbal-Ahmadi, M., Hatalski, C. G., Avishai-Eliner, S., and Baram, T. Z. (1997). Corticotropin releasing factor receptor type II (CRF2) messenger ribonucleic acid levels in the hypothalamic ventromedial nucleus of the infant rat are reduced by maternal deprivation. Endocrinology 138, 5048-5051.

Elmquist, J. K., Bjorbaek, C., Ahima, R. S., Flier, J. S., and Saper, C. B. (1998). Distributions of leptin receptor mRNA isoforms in the rat brain. J. Comp. Neurol. 395, 535-547.

Fahrbach, S. E., Morrell, J. I., and Pfaff, D. W. (1989). Studies of ventromedial hypothalamic afferents in the rat using three methods of HRP application. Exp. Brain Res. 77, 221-233.

Fei, H., Okano, H. J., Li, C., Lee, G. H., Zhao, C., Darnell, R., et al. (1997). Anatomic localization of alternatively spliced leptin receptors (Ob-R) in mouse brain and other tissues. Proc. Natl. Acad. Sci. U.S.A. 94, 70017005 .

Fekete, E. M., Inoue, K., Zhao, Y., Rivier, J. E., Vale, W. W., Szucs, A., etal. (2007). Delayed satietylike actions and altered feeding microstructure by a selective type 2 corticotropin-releasing factor agonist in rats: intra-hypothalamic urocortin 3 administration reduces food intake by prolonging the post-meal interval. Neuropsychopharmacology 32, 10521068.

Flanagan-Cato, L. M. (2011). Sex differences in the neural circuit that mediates female sexual receptivity. Front. Neuroendocrinol. 32, 124-136.

Fremeau, R. T. Jr., Troyer, M. D., Pahner, I., Nygaard, G. O., Tran, C. H., Reimer, R. J., et al. (2001). 
The expression of vesicular glutamate transporters defines two classes of excitatory synapse. Neuron 31, 247-260.

Gardner, J. D., Rothwell, N. J., and Luheshi, G. N. (1998). Leptin affects food intake via CRF-receptormediated pathways. Nat. Neurosci. $1,103$.

Goland, R. S. (1986). High Levels of Corticotropin-Releasing Hormone Immunoactivity in Maternal and Fetal Plasma during Pregnancy. J. Clin. Endocrinol. Metab. 63, 11991203.

Graham, C. E., Basappa, J., and Vetter, D. E. (2010). A corticotropinreleasing factor system expressed in the cochlea modulates hearing sensitivity and protects against noiseinduced hearing loss. Neurobiol. Dis. 38, 246-258.

Grammatopoulos, D. K. (2000). Urocortin, but not corticotropinreleasing hormone $(\mathrm{CRH})$, activates the mitogen-activated protein kinase signal transduction pathway in human pregnant myometrium: an effect mediated via R1 and R2 CRH receptor subtypes and stimulation of Gq-proteins. Mol. Endocrinol. 14, 2076-2091.

Gurdjian, E. S. (1927). The diencephalon of the albino rat. Studies on the brain of the rat. No. 2. J. Comp. Neurol. 43, 1-114.

Harris, R. B. (2010). Leptin responsiveness of mice deficient in corticotrophin-releasing hormone receptor type 2. Neuroendocrinology 92, 198-206.

Hashimoto, K., Nishiyama, M., Tanaka, Y., Noguchi, T., Asaba, K., Hossein, P. N., et al. (2004). Urocortins and corticotropin releasing factor type 2 receptors in the hypothalamus and the cardiovascular system. Peptides 25, 1711-1721.

Herzog, E., Bellenchi, G. C., Gras, C. Bernard, V., Ravassard, P., Bedet, C., etal. (2001). The existence of a second vesicular glutamate transporter specifies subpopulations of glutamatergic neurons. J. Neurosci. 21, RC181.

Hinkle, R. T., Donnelly, E., Cody, D. B., Samuelsson, S., Lange, J. S., Bauer, M. B., et al. (2003). Activation of the CRF 2 receptor modulates skeletal muscle mass under physiological and pathological conditions. Am. J. Physiol. Endocrinol. Metab. 285, E889-E898.

Hsu, S. Y., and Hsueh, A. J. (2001). Human stresscopin and stresscopinrelated peptide are selective ligands for the type 2 corticotropin-releasing hormone receptor. Nat. Med. 7, 605-611.
Inoue, S., Campfield, L. A., and Bray, G. A. (1977). Comparison of metabolic alterations in hypothalamic and high fat diet-induced obesity. Am. J. Physiol. 233, R162-R168.

Jamieson, P. M., Cleasby, M. E., Kuperman, Y., Morton, N. M., Kelly, P. A., Brownstein, D. G., et al. (2011). Urocortin 3 transgenic mice exhibit a metabolically favourable phenotype resisting obesity and hyperglycaemia on a high-fat diet. Diabetologia 54 2392-2403.

Jamieson, P. M., Li, C., Kukura, C., Vaughan, J., and Vale, W (2006). Urocortin 3 modulates the neuroendocrine stress response and is regulated in rat amygdala and hypothalamus by stress and glucocorticoids. Endocrinology 147, 45784588.

Kang, L., Routh, V. H., Kuzhikandathil, E. V., Gaspers, L. D., and Levin, B. E. (2004). Physiological and molecular characteristics of rat hypothalamic ventromedial nucleus glucosensing neurons. Diabetes 53, 549-559.

Kanno, T. (1999). Corticotropinreleasing factor modulation of $\mathrm{Ca}^{2+}$ influx in rat pancreatic beta-cells. Diabetes 48, 1741-1746.

Kiang, J. G. (1997). Corticotropinreleasing factor-like peptides increase cytosolic $\mathrm{Ca}^{2+}$ in human epidermoid A-431 cells. Eur. J. Pharmacol. 329, 237-244.

Kim, K. W., Zhao, L., Donato, J. Jr., Kohno, D., Xu, Y., Elias, C. F., et al. (2011). Steroidogenic factor 1 directs programs regulating dietinduced thermogenesis and leptin action in the ventral medial hypothalamic nucleus. Proc. Natl. Acad. Sci. U.S.A. 108, 10673-10678.

King, B. M. (2006). The rise, fall, and resurrection of the ventromedial hypothalamus in the regulation of feeding behavior and body weight. Physiol. Behav. 87, 221-244.

Kita, H., and Oomura, Y. (1982). An HRP study of the afferent connections to rat medial hypothalamic region. Brain Res. Bull. 8, 53-62.

Kostich, W. A., Chen, A., Sperle, K. and Largent, B. L. (1998). Molecular identification and analysis of a novel human corticotropin-releasing factor (CRF) receptor: the CRF2 $\gamma$ receptor. Mol. Endocrinol. 12, 1077-1085.

Kozicz, T., Yanaihara, H., and Arimura, A. (1998). Distribution of urocortinlike immunoreactivity in the central nervous system of the rat. J Comp. Neurol. 391, 1-10.

Kreier, F., Fliers, E., Voshol, P. J., Van Eden, C. G., Havekes, L. M., Kalsbeek, A., et al. (2002). Selective parasympathetic innervation of subcutaneous and intra-abdominal fat - functional implications. J. Clin. Invest. 110, 1243-1250.

Kreier, F., Kap, Y. S., Mettenleiter, T. C., Van Heijningen, C., Van Der Vliet, J., Kalsbeek, A., et al. (2006). Tracing from fat tissue, liver, and pancreas: a neuroanatomical framework for the role of the brain in type 2 diabetes. Endocrinology 147, 1140-1147.

Kumon, A., Takahashi, A., Hara, T., and Shimazu, T. (1976). Mechanism of lipolysis induced by electrical stimulation of the hypothalamus in the rabbit. J. Lipid Res. 17, 551-558.

Kuperman, Y., Issler, O., Regev, L., Musseri, I., Navon, I., NeufeldCohen, A., et al. (2010). Perifornical Urocortin-3 mediates the link between stress-induced anxiety and energy homeostasis. Proc. Natl. Acad. Sci. U.S.A. 107, 8393-8398.

Kuperman, Y., Issler, O., Vaughan, J., Bilezikjian, L., Vale, W., and Chen, A. (2011). Expression and regulation of corticotropin-releasing factor receptor type 2beta in developing and mature mouse skeletal muscle. Mol. Endocrinol. 25, 157-169.

Kurrasch, D. M., Cheung, C. C., Lee, F. Y., Tran, P. V., Hata, K., and Ingraham, H. A. (2007). The neonatal ventromedial hypothalamus transcriptome reveals novel markers with spatially distinct patterning. J. Neurosci. 27, 13624-13634.

Latchman, D. S. (2002). Urocortin. Int J. Biochem. Cell Biol. 34, 907-910.

Levin, B. E., Routh, V. H., Kang, L., Sanders, N. M., and Dunn-Meynell, A. A. (2004). Neuronal glucosensing: what do we know after 50 years? Diabetes 53, 2521-2528.

Lewis, K., Li, C., Perrin, M. H., Blount, A., Kunitake, K., Donaldson, C., et al. (2001). Identification of urocortin III, an additional member of the corticotropin-releasing factor (CRF) family with high affinity for the CRF2 receptor. Proc. Natl. Acad. Sci. U.S.A. 98, 7570-7575.

Li, C., Chen, P., Vaughan, J., Blount, A., Chen, A., Jamieson, P. M., et al (2003). Urocortin III is expressed in pancreatic beta-cells and stimulates insulin and glucagon secretion. Endocrinology 144, 3216-3224.

Li, C., Chen, P., Vaughan, J., Lee, K. F., and Vale, W. (2007). Urocortin 3 regulates glucose-stimulated insulin secretion and energy homeostasis. Proc. Natl. Acad. Sci. U.S.A. 104, 4206-4211.

Li, C., and Vale, W. (2002). Regulation of Urocortin III mRNA expression in the ob/ob obese mouse: involvement of leptin. Endocr. Soc. Abstr. 84, 198.
Li, C., Vaughan, J., Sawchenko, P. E., and Vale, W. W. (2002). Urocortin III-immunoreactive projections in rat brain: partial overlap with sites of type 2 corticotrophinreleasingFfactor receptor expression. J. Neurosci. 22, 991-1001.

Lin, D., Boyle, M. P., Dollar, P., Lee, H., Lein, E. S., Perona, P., et al. (2011). Functional identification of an aggression locus in the mouse hypothalamus. Nature 470, 221-226.

Lindberg, D. R., Chen, P., and Li, C. (2011). Mapping the efferent projections of urocortin-3 sensitive neurons of the ventromedial hypothalamic nucleus. Soc. Neurosci. Abstr. 601.16, SS17.

Luiten, P. G., and Room, P. (1980). Interrelations between lateral, dorsomedial and ventromedial hypothalamic nuclei in the rat. An HRP study. Brain Res. 190, 321-332.

Luo, X., Ikeda, Y., and Parker, K. L. (1994). A cell-specific nuclear receptor is essential for adrenal and gonadal development and sexual differentiation. Cell 77, 481-490.

Makino, S., Asaba, K., Nishiyama, M., and Hashimoto, K. (1999). Decreased type 2 corticotropin-releasing hormone receptor mRNA expression in the ventromedial hypothalamus during repeated immobilization stress. Neuroendocrinology 70, 160-167.

Makino, S., Nishiyama, M., Asaba, K., Gold, P. W., and Hashimoto, K. (1998). Altered expression of type 2 $\mathrm{CRH}$ receptor mRNA in the $\mathrm{VMH}$ by glucocorticoids and starvation. Am. J. Physiol. 275, R1138-R1145.

Maras, P. M., and Petrulis, A. (2010). Anatomical connections between the anterior and posterodorsal subregions of the medial amygdala: integration of odor and hormone signals. Neuroscience 170, 610-622.

Martinez, V., Wang, L., Million, M., Rivier, J., and Tache, Y. (2004). Urocortins and the regulation of gastrointestinal motor function and visceral pain. Peptides 25, 1733-1744.

McBride, R. L., and Sutin, J. (1977). Amygdaloid and pontine projections to the ventromedial nucleus of the hypothalamus. J. Comp. Neurol. 174, 377-396.

McCrimmon, R. J., Song, Z., Cheng, H., Mcnay, E. C., Weikart-Yeckel, C., Fan, X., et al. (2006). Corticotrophinreleasing factor receptors within the ventromedial hypothalamus regulate hypoglycemia-induced hormonal counterregulation. J. Clin. Invest. 116, 1723-1730.

Morrison, S. F., Nakamura, K., and Madden, C. J. (2008). Central control 
of thermogenesis in mammals. Exp. Physiol. 93, 773-797.

Musatov, S., Chen, W., Pfaff, D. W. Kaplitt, M. G., and Ogawa, S. (2006). RNAi-mediated silencing of estrogen receptor $\{$ alpha $\}$ in the ventromedial nucleus of hypothalamus abolishes female sexual behaviors. Proc. Natl. Acad. Sci. U.S.A. 103, 10456-10460.

Musatov, S., Chen, W., Pfaff, D. W., Mobbs, C. V., Yang, X. J., Clegg, D. J., et al. (2007). Silencing of estrogen receptor alpha in the ventromedial nucleus of hypothalamus leads to metabolic syndrome. Proc. Natl. Acad. Sci. U.S.A. 104, 2501-2506.

Niijima, A., Rohner-Jeanrenaud, F., and Jeanrenaud, B. (1984). Role of ventromedial hypothalamus on sympathetic efferents of brown adipose tissue. Am. J. Physiol. 247, R650R654.

Nishiyama, M., Makino, S., Asaba, K., and Hashimoto, K. (1999). Leptin effects on the expression of type- 2 $\mathrm{CRH}$ receptor mRNA in the ventromedial hypothalamus in the rat. $J$. Neuroendocrinol. 11, 307-314.

Northcutt, K. V., and Lonstein, J. S. (2011). Neuroanatomical projections of the species-specific tyrosine hydroxylase-immunoreactive cells of the male prairie vole bed nucleus of the stria terminalis and medial amygdala. Brain Behav. Evol. 77, 176-192.

Ohata, H., and Shibasaki, T. (2004). Effects of urocortin 2 and 3 on motor activity and food intake in rats. Peptides 25, 1703-1709.

Ohata, H., Suzuki, K., Oki, Y., and Shibasaki, T. (2000). Urocortin in the ventromedial hypothalamic nucleus acts as an inhibitor of feeding behavior in rats. Brain Res. 861, 1-7.

Parker, K. L., Rice, D. A., Lala, D. S., Ikeda, Y., Luo, X., Wong, M., et al. (2002). Steroidogenic factor 1: an essential mediator of endocrine development. Recent Prog. Horm. Res. 57, 19-36.

Pelleymounter, M. A., Joppa, M., Carmouche, M., Cullen, M. J., Brown, B., Murphy, B., et al. (2000). Role of corticotropin-releasing factor (CRF) receptors in the anorexic syndrome induced by CRF. J. Pharmacol. Exp. Ther. 293, 799-806.

Perkins, M. N., Rothwell, N. J., Stock, M. J., and Stone, T. W. (1981). Activation of brown adipose tissue thermogenesis by the ventromedial hypothalamus. Nature 289, 401-402.

Perrin, M., Donaldson, C., Chen, R., Blount, A., Berggren, T., Bilezikjian, L., et al. (1995). Identification of a second corticotropin-releasing factor receptor gene and characterization of a cDNA expressed in heart. Proc. Natl. Acad. Sci. U.S.A. 92, 2969-2973.

Perrin, M. H., and Vale, W. W. (1999). Corticotropin releasing factor receptors and their ligand family. Ann. N. Y. Acad. Sci. 885, 312-328.

Porcher, C., Juhem, A., Peinnequin, A., Sinniger, V., and Bonaz, B. (2005). Expression and effects of metabotropic CRF1 and CRF2 receptors in rat small intestine. Am. J. Physiol. Gastrointest. Liver Physiol. 288, G1091-G1103.

Poulin, A.-M., Lenglos, C., Mitra, A., and Timofeeva, E. (2012). Hypothalamic expression of urocortin 3 and the type 2 corticotropin-releasing factor receptor is regulated according to feeding state in lean but not obese Zucker rats. Neuropharmacology 63, 147-153.

Rabadan-Diehl, C., Kiss, A., Camacho, C., and Aguilera, G. (1996). Regulation of messenger ribonucleic acid for corticotropin releasing hormone receptor in the pituitary during stress. Endocrinology 137, 3808-3814.

Radley, J. J., and Sawchenko, P. E. (2011). A common substrate for prefrontal and hippocampal inhibition of the neuroendocrine stress response. J. Neurosci. 31, 9683-9695.

Reyes, T. M., Lewis, K., Perrin, M. H., Kunitake, K. S., Vaughan, J., Arias, C. A., et al. (2001). Urocortin II: A member of the corticotropin-releasing factor (CRF) neuropeptide family that is selectively bound by type $2 \mathrm{CRF}$ receptors. Proc. Natl. Acad. Sci. U.S.A 98, 2843-2848.

Richard, D., Rivest, R., Naimi, N., Timofeeva, E., and Rivest, S. (1996). Expression of corticotropin-releasing factor and its receptors in the brain of lean and obese Zucker rats. Endocrinology 137, 4786-4795.

Ritter, R. C. (2004). Gastrointestinal mechanisms of satiation for food. Physiol. Behav. 81, 249-273.

Ruffin, M., and Nicolaidis, S. (1999). Electrical stimulation of the ventromedial hypothalamus enhances both fat utilization and metabolic rate that precede and parallel the inhibition of feeding behavior. Brain Res. 846, 23-29.

Ryabinin, A. E., Tsoory, M. M., Kozicz, T., Thiele, T. E., Neufeld-Cohen, A., Chen, A., et al. (2012). Urocortins: CRF's siblings and their potential role in anxiety, depression and alcohol drinking behavior. Alcohol 46, 349-357.

Sadovsky, Y., Crawford, P. A., Woodson, K. G., Polish, J. A., Clements, M. A., Tourtellotte, L. M., et al. (1995). Mice deficient in the orphan receptor steroidogenic factor 1 lack adrenal glands and gonads but express P450 side-chain-cleavage enzyme in the placenta and have normal embryonic serum levels of corticosteroids. Proc. Natl. Acad. Sci. U.S.A. 92, 10939-10943.

Sakaguchi, T., Takahashi, M., and Bray, G. A. (1988). Diurnal changes in sympathetic activity. Relation to food intake and to insulin injected into the ventromedial or suprachiasmatic nucleus. J. Clin. Invest. 82 , 282-286.

Saper, C. B., Swanson, L. W., and Cowan, W. M. (1976). The efferent connections of the ventromedial nucleus of the hypothalamus of the rat. J. Comp. Neurol. 169, 409-442.

Sawchenko, P. E., and Swanson, L. W. (1983). The organization of forebrain afferents to the paraventricular and supraoptic nuclei of the rat. J. Comp. Neurol. 218, 121-144.

Segal, J. P., Stallings, N. R., Lee, C. E., Zhao, L., Socci, N., Viale, A., et al. (2005). Use of laser-capture microdissection for the identification of marker genes for the ventromedial hypothalamic nucleus. J. Neurosci. 25, 4181-4188.

Shinoda, K., Lei, H., Yoshii, H., Nomura, M., Nagano, M., Shiba, H., et al. (1995). Developmental defects of the ventromedial hypothalamic nucleus and pituitary gonadotroph in the FtzF1 disrupted mice. Dev. Dyn. 204, 22-29.

Smagin, G. N., Howell, L. A., Ryan, D. H., De Souza, E. B., and Harris, R B. (1998). The role of CRF2 receptors in corticotropin-releasing factor- and urocortin-induced anorexia. $\mathrm{Neu}$ roreport 11, 1601-1606.

Solinas, G., Summermatter, S., Mainieri, D., Gubler, M., Montani, J. P., Seydoux, J., et al. (2006). Corticotropin-releasing hormone directly stimulates thermogenesis in skeletal muscle possibly through substrate cycling between de novo lipogenesis and lipid oxidation. Endocrinology 147, 31-38.

Spina, M., Merlo-Pich, E., Basso, A. M., Rivier, J., Vale, W., and Koob, G. F. (1996). Appetite-suppressing effects of urocortin, a CRF-related neuropeptide. Science 273, 15611564.

Stengel, A., and Tache, Y. (2009). Neuroendocrine control of the gut during stress: corticotropin-releasing factor signaling pathways in the spotlight. Annu. Rev. Physiol. 71, 219-239.

Stenzel, P., Kesterson, R., Yeung, W., Cone, R. D., Rittenberg, M. B., and Stenzel-Poore, M. P. (1995). Identification of a novel murine receptor for corticotropin-releasing hormone expressed in the heart. Mol. Endocrinol. 9, 637-645.

Sternson, S. M., Shepherd, G. M. G., and Friedman, J. M. (2005). Topographic mapping of $\mathrm{VMH}->$ arcuate nucleus microcircuits and their reorganization by fasting. Nat. Neurosci. 8, 1356-1363.

Swanson, L. W., and Petrovich, G. D. (1998). What is the amygdala? Trends Neurosci. 21, 323-331.

Swanson, L. W., Sawchenko, P. E., Rivier, J., and Vale, W. W. (1983). Organization of ovine corticotropin-releasing factor immunoreactive cells and fibers in the rat brain: an immunohistochemical study. Neuroendocrinology 36, 165-186.

Tabarin, A., Diz-Chaves, Y., Consoli, D., Monsaingeon, M., Bale, T. L., Culler, M. D., et al. (2007). Role of the corticotropin-releasing factor receptor type 2 in the control of food intake in mice: a meal pattern analysis. Eur. J. Neurosci. 26, 2303-2314.

Tache, Y., and Bonaz, B. (2007). Corticotropin-releasing factor receptors and stress-related alterations of gut motor function. J. Clin. Invest. 117, 33-40.

Takahashi, A., and Shimazu, T. (1981). Hypothalamic regulation of lipid metabolism in the rat: effect of hypothalamic stimulation on lipolysis. J. Auton. Nerv. Syst. 4, 195-205.

Takamori, S., Rhee, J. S., Rosenmund, C., and Jahn, R. (2001). Identification of differentiation-associated brain-specific phosphate transporter as a second vesicular glutamate transporter (VGLUT2). J. Neurosci. 21, RC182.

Telegdy, G., and Adamik, A. (2008). Involvement of $\mathrm{CRH}$ receptors in urocortin-induced hyperthermia. Peptides 29, 1937-1942.

Telegdy, G., Adamik, A., and Tóth, G. (2006). The action of urocortins on body temperature in rats. Peptides 27, 2289-2294.

Tong, Q., Ye, C., Mccrimmon, R. J., Dhillon, H., Choi, B., Kramer, M. D., et al. (2007). Synaptic glutamate release by ventromedial hypothalamic neurons is part of the neurocircuitry that prevents hypoglycemia. Cell Metab. 5, 383-393.

Uehara, Y., Shimizu, H., Ohtani, K., Sato, N., and Mori, M. (1998). Hypothalamic corticotropinreleasing hormone is a mediator of the anorexigenic effect of leptin. Diabetes 47, 890-893.

Vale, W., Spiess, J., Rivier, C., and Rivier, J. (1981). Characterization of a 41 residue ovine hypothalamic peptide 
that stimulates the secretion of corticotropin and $\beta$-endorphin. Science 213, 1394-1397.

Van Hover, C., Chen, P., and Li, C. (2011). Stress-activated afferent inputs into the medial amygdala: Implication of neuropathways mediating stress-activation of Urocortin 3 neurons in the amygdala. Soc. Neurosci. Abstr. 191.14, UU27.

Van Pett, K., Viau, V., Bittencourt, J. C., Chan, R. K. W., Li, H.-Y., Arias, C., et al. (2000). Distribution of mRNAs encoding CRF receptors in brain and pituitary of rat and mouse. J. Comp. Neurol. 428, 191-212.

Vaughan, J. M., Donaldson, C., Bittencourt, J., Perrin, M. H., Lewis, K., Sutton, S., et al. (1995). Urocortin, a mammalian neuropeptide related to fish urotensin I and to corticotropinreleasing factor. Nature 378, 287-292.

Venihaki, M., Sakihara, S., Subramanian, S., Dikkes, P., Weninger, S. C., Liapakis, G., et al. (2004). Urocortin III, a brain neuropeptide of the corticotropin-releasing hormone family: modulation by stress and attenuation of some anxiety-like behaviours. J. Neuroendocrinol. 16 411-422.

Vetter, D. E., Li, C., Zhao, L., Contarino, A., Liberman, M. C., Smith, G. W., et al. (2002). Urocortin-deficient mice show hearing impairment and increased anxiety-like behavior. Nat. Genet. 31, 363-369.

Wang, C., and Kotz, C. (2002). Urocortin in the lateral septal area modulates feeding induced by orexin A in the lateral hypothalamus. Am. J. Physiol. Regul. Integr. Comp. Physiol. 283, R358-R367.

Wiley, K. E., and Davenport, A. P. (2004). CRF2 receptors are highly expressed in the human cardiovascular system and their cognate ligands urocortins 2 and 3 are potent vasodilators. Br. J. Pharmacol. 143, 508-514.

Wolfgang, M. J., Cha, S. H., Sidhaye, A., Chohnan, S., Cline, G.,
Shulman, G. I., et al. (2007). Regulation of hypothalamic malonyl-CoA by central glucose and leptin. Proc. Natl. Acad. Sci. U.S.A. 104, 19285 19290.

Zaborszky, L. (1982). Afferent connections of the medial basal hypothalamus. Adv. Anat. Embryol. Cell Biol. 69, 1-107.

Ziegler, D. R., Cullinan, W. E., and Herman, J. P. (2002). Distribution of vesicular glutamate transporter mRNA in rat hypothalamus. J. Comp. Neurol. 448, 217-229.

Zigman, J. M. (2003). Minireview: from anorexia to obesity-the yin and yang of body weight control. Endocrinology 144, 3749-3756.

Conflict of Interest Statement: The authors declare that the research was conducted in the absence of any commercial or financial relationships that could be construed as a potential conflict of interest.

Received: 01 October 2012; paper pending published: 22 October 2012; accepted: 18 December 2012; published online: 07 January 2013.

Citation: Chen P, Van Hover C, Lindberg $D$ and Li C (2013) Central urocortin 3 and type 2 corticotropin-releasing factor receptor in the regulation of energy homeostasis: critical involvement of the ventromedial hypothalamus. Front. Endocrin. 3:180. doi: 10.3389/fendo.2012.00180

This article was submitted to Frontiers in Neuroendocrine Science, a specialty of Frontiers in Endocrinology.

Copyright (c) 2013 Chen, Van Hover, Lindberg and Li. This is an open-access article distributed under the terms of the Creative Commons Attribution License, which permits use, distribution and reproduction in other forums, provided the original authors and source are credited and subject to any copyright notices concerning any third-party graphics etc. 